\title{
BIOLOGICAL DIVERSITY OF FARM ANIMALS IN BANGLADESH: A REVIEW
}

\author{
M.A. Hamid ${ }^{*}$ \\ School of Agriculture and Rural Development, Bangladesh Open University \\ Gazipur-1705, Bangladesh
}

\begin{abstract}
The present study attempts to examine the scenario of farm animal's genetic diversity and their distribution pattern in Bangladesh. The major components of farm animals in Bangladesh are cattle, buffalo, goat, sheep, chicken and duck which are being raised in a mixed farming system integrated with crop agriculture. The biological diversity most of farm animals is of native origin. Cattle and chicken are the two major species which are being manipulated genetically either through inclusion of exotic blood and/or import of live animals and birds. Buffalo, goat, sheep and duck are also being crossed to some extent with exotic germplasms. Other species like pigeon, quail, and guinea fowl are also available in the country. This paper has also shown the population and list of different breed/type of farm animals available in Bangladesh which helps to meet the public priorities such as, their production and reproduction, their management practices, their survivability etc.
\end{abstract}

Keywords: Domestic animal, Birds, Genetic diversity

\section{INTRODUCTION}

The term, biodiversity or biological diversity denotes "the variety of life on earth". It refers, particularly, to the differences between living organisms at different level of biological organization: gene, individual species and ecosystems. Bangladesh is very rich in biodiversity. The rich genetic diversity in crops, livestock, fish, trees and wildlife directly and indirectly support the lives and livelihoods of the people of the country by supplying wide range of provisional, regulatory and cultural services.

Livestock species of Bangladesh includes cattle, buffalo, goat, sheep, chicken and duck. Other important species are horse, pig, geese, pigeon, guinea fowl, elephant, deer and gayal the latter three living principally in special forest areas. The overall contribution of livestock to agricultural production is $14.08 \%$ (Hamid et al., 2017a). In addition, livestock contribute $95 \%$ of draft power, $50 \%$ of rural transport and $25 \%$

\footnotetext{
* Corresponding author: drmahamid.bou@gmail.com
} 
of fuel for cooking in the country (DLS, 2016). Over $85 \%$ of livestock are raised by smallholder farmers who own 1-2 head of cattle, 2-3 head of sheep and goats and a few head of poultry and for whom the special characteristics of indigenous livestock adaptability to harsh climate and poor nutrition, resistance to endemic diseases and parasites are crucial.

Livestock plays an important role in the national economy of Bangladesh. The livestock sub-sector that includes poultry offers important employment and livelihood opportunities particularly for the rural poor, including the functionally landless, many of whom regard livestock as a main livelihood option. The contribution of livestock to GDP is $2.5 \%$ (DLS, 2014) and the overall trend of the livestock in Bangladesh has also been increasing (DLS, 2014). Moreover, the products from livestock; like milk, meat and egg have also shown increasing trend of production (DLS, 2014).

In Bangladesh, during the last decade a large number of non-descriptive cattle have been replaced by cross-bred cattle. It was started in 1958 by Directorate of Livestock Services (DLS) with artificial insemination (AI) program which was strengthened in 1975-76. In 1960s, Savar Dairy Farm was established for dairy development program of the country The farm started to work with Shindhi, Shahiwal and Tharparkar breed to cross with indigenous cattle. In 1973, some Friesian and Jersey bull were imported from Australia and this was the initiating point of new dimension. These bulls were used for semen production for upgrading the indigenous cattle. In 1975, the AI program was extended throughout the country for cattle development. Haque, 2014 stated that there are 2.3 million high yielding cross bred cattle are available in Bangladesh. They can produce $1800-3000 \mathrm{~kg}$ milk in a lactation period, if they are well managed. The animals get mature at the age of 18-24 months and have calving interval of 13-15 months.

Although Bangladesh is rich in biodiversity (species) but unfortunately, many plant and animal are facing severe threats to their survival and are disappearing at alarming rates. And human actions are the cause behind this biological degradation. However, there are no documented research studies so far that investigated the farm animal's biological diversity of the country. The purpose of this study is to estimate the present scenario of farm animal's biodiversity and their distribution pattern in Bangladesh.

\section{Farm Animals and Their Biodiversity in Bangladesh}

Cattle, buffalo, goat, sheep, chicken and duck as major components of farm animals in Bangladesh. Most of them are being raised in a mixed farming system integrated with crop agriculture and their biological diversity is of native origin. Cattle and chicken are the two major species of farm animals and they are being manipulated genetically either through inclusion of exotic blood and/or import of live animals and birds. Buffalo, goat, sheep and duck are also being crossed to some extent with exotic germplasms. The farm animals and their biodiversity of Bangladesh are as follows:- 


\section{Cattle}

The indigenous cattle are considered potential in some locality and are identified by its local name, such as Pabna cattle, Red Chittagong cattle, North Bengal Grey cattle, Munshiganj cattle and Non-descript native cattle (Hamid et al., 2017b). Mating with Bos indicus bulls started in 1936 in some localities and resulted in improved cattle in the selected areas of the country. Artificial insemination program started in 1958 and is widely extended in the country and a good number of crossbred cattle have already been added to the herd of different parts of the country (DLS, 2010). Thus, cattle population of the country consists of i) Indigenous type ii) Exotic type (Holestein, Friesian, Holestein and Friesian, Shahiwal, Sindhi, Hariana and Jersey etc.) and iii) Crossbred type (DLS, 2010).

BLRI, 2004 stated that, there are about four (4) local varieties and four (4) exotic breeds of cattle are reared in the country (Table 1). All the local varieties (Pabna, Red Chittagong, North Bengal Grey, Munshiganj) are at the risk of extinction due to indiscriminate use of cross breeding programs throughout the country. Farmers interest for more milk, absence of initiatives for conservation of local variety and absence of organized programs for identification and characterization of their production and reproduction performances in the past or even in the present lead to the local cattle germplasms at risk. All the cattle germplasms reached at the risk of extinction were used widely. During the last 50 years the country already lost potential local cattle germplasms and Jersey exotic breed.

Table 1. Breed Diversity (Number of Breeds) in Bangladesh

\begin{tabular}{l|c|c|c|c|c|c|c|c|c|c}
\hline \multirow{2}{*}{ Species } & \multicolumn{10}{c}{ Number of Breeds } \\
\cline { 2 - 12 } & \multicolumn{2}{c}{ Current Total } & \multicolumn{2}{c}{ At risk } & \multicolumn{2}{c}{ Widely } & \multicolumn{2}{c}{ Others } & \multicolumn{2}{c}{$\begin{array}{c}\text { Lost } \\
\text { (Last 50 yr) }\end{array}$} \\
\cline { 2 - 12 } & L & E & L & E & L & E & L & E & L & E \\
\hline Cattle & 4 & 4 & 4 & - & 4 & 1 & 1 & - & 1 & 1 \\
Buffalo & 4 & 1 & - & 1 & 4 & 1 & - & - & - & 1 \\
Goat & 1 & 1 & - & - & 1 & - & - & - & - & - \\
Sheep & 1 & - & - & - & 1 & - & - & - & - & 3 \\
Chicken & 6 & 15 & 3 & - & 3 & 10 & - & - & - & - \\
Duck & 3 & 4 & - & - & 3 & 3 & - & - & - & - \\
Pigeon & 1 & 6 & - & - & 1 & - & - & - & - & - \\
Quail & 2 & 3 & 1 & - & - & 1 & - & - & - & - \\
Guinea fowl & 1 & - & - & - & 1 & - & - & - & - & - \\
\hline
\end{tabular}

Source: BLRI, 2004; L=Local, E=Exotic 
The cattle populations of Bangladesh during last 10 years are presented in Table 2. The list of indigenous, exotic and crossbred cattle genetic diversity and their distribution in Bangladesh are presented in Table 3.

Namikawa et al. (1987) reported the blood groups, blood protein polymorphism and karyotypes of the native cattle. They reported the blood protein polymorphism for 6 loci. These are haemoglobin, albumin, transferrin, carbonic anhydrase, amulase-I and diaphorase-II. The most frequently occurred genes were $H b b^{A}, A l b^{B}, T f D^{2}, A m-1 B$, $C A^{S}$ and Dia-II ${ }^{c}$. They detected 9 blood group systems. These were A, B, C, F, L, J, $\mathrm{S}, \mathrm{Z}$ and R'. They found 60 chromosomes in diploid cells of native cattle, 58 autosomal chromosomes were acrocentric, $\mathrm{X}$ and $\mathrm{Y}$ chromosome (sex chromosome) were submetacentric and acrocentric, respectively.

Table 2. Livestock population of Bangladesh during last 10 years

\begin{tabular}{l|c|c|c|c|c|c|c|c|c|c}
\hline $\begin{array}{c}\text { Livestock } \\
\text { Species }\end{array}$ & $\begin{array}{c}2009- \\
10\end{array}$ & $\begin{array}{c}2010- \\
11\end{array}$ & $\begin{array}{c}2011- \\
12\end{array}$ & $\begin{array}{c}2012- \\
13\end{array}$ & $\begin{array}{c}2013- \\
14\end{array}$ & $\begin{array}{c}2014- \\
15\end{array}$ & $\begin{array}{c}2015- \\
16\end{array}$ & $\begin{array}{c}2016- \\
17\end{array}$ & $\begin{array}{c}2017- \\
18\end{array}$ & $2018-19$ \\
\hline Cattle & 230.51 & 231.21 & 231.95 & 233.41 & 234.88 & 236.36 & 237.85 & 239.35 & 240.86 & 242.38 \\
Buffalo & 13.49 & 13.94 & 14.43 & 14.50 & 14.57 & 14.64 & 14.71 & 14.78 & 14.79 & 14.86 \\
Sheep & 29.77 & 30.02 & 30.82 & 31.43 & 32.06 & 32.70 & 33.35 & 34.01 & 34.68 & 35.37 \\
Goat & 232.75 & 241.49 & 251.16 & 252.77 & 254.39 & 256.02 & 257.66 & 259.31 & 261.00 & 262.67 \\
Chicken & 2280.35 & 2346.86 & 2428.66 & 2490.11 & 2553.11 & 2617.70 & 2683.93 & 2751.83 & 2821.45 & 2892.83 \\
Duck & 426.77 & 441.20 & 457.00 & 472.54 & 488.61 & 505.22 & 522.40 & 540.16 & 558.53 & 577.52 \\
\hline
\end{tabular}

Source: DLS, 2019

Table 3. List of Indigenous, Exotic and Crossbred Cattle Genetic diversity and their distribution in Bangladesh

\begin{tabular}{l|l|l|l}
\hline Genetic diversity & \multicolumn{1}{c|}{ Breed/Type } & Geographic distribution & \multicolumn{1}{c}{$\begin{array}{c}\text { Agro-ecological } \\
\text { Zone }\end{array}$} \\
\hline Indigenous & Non-descript Deshi & Throughout the country & $\begin{array}{l}\text { All agro-ecological } \\
\text { (30) zones }\end{array}$ \\
& Red Chittagong & $\begin{array}{l}\text { Chittagong district and } \\
\text { Chittagong Hill Tract }\end{array}$ & $\begin{array}{l}\text { Chittagong coastal } \\
\text { plain }\end{array}$ \\
& Pabna & $\begin{array}{l}\text { Sirajgonj and Pabna } \\
\text { district }\end{array}$ & $\begin{array}{l}\text { Active Brahmaputra } \\
\text { \& Jamuna flood plain }\end{array}$ \\
& Northern regions of & Bangladesh more \\
& North Bengal Grey & $\begin{array}{l}\text { Tista meander flood } \\
\text { plain and lowers atrai } \\
\text { division }\end{array}$ & basin \\
& & &
\end{tabular}




\begin{tabular}{|c|c|c|c|}
\hline Genetic diversity & Breed/Type & Geographic distribution & $\begin{array}{l}\text { Agro-ecological } \\
\text { Zone }\end{array}$ \\
\hline & Munshigonj & $\begin{array}{l}\text { Munshigong and } \\
\text { Manikgonj district }\end{array}$ & $\begin{array}{l}\text { Young Brahmaputra } \\
\text { and Jamuna flood } \\
\text { plain }\end{array}$ \\
\hline & Madaripur & Madaripur district & $\begin{array}{l}\text { Low Ganges river } \\
\text { flood plain }\end{array}$ \\
\hline \multirow{4}{*}{ Exotic } & Holstein Friesian & Government Farm & \\
\hline & Jersey & $\begin{array}{l}\text { Government Farm } \\
\& \text { BMPCUL }\end{array}$ & $\begin{array}{l}\text { All agro-ecological } \\
\text { zones }\end{array}$ \\
\hline & Sahiwal & Government Farm & \\
\hline & $\begin{array}{l}\text { Holstein Friesian } \\
\text { cross }\end{array}$ & All over the country & \\
\hline \multirow[t]{2}{*}{ Crossbred } & Jersey cross & $\begin{array}{l}\text { Only in the milk pocket } \\
\text { in the western part }\end{array}$ & $\begin{array}{l}\text { All agro-ecological } \\
\text { zones }\end{array}$ \\
\hline & Sahiwal cross & All over the country & \\
\hline
\end{tabular}

Source: BLRI, 2015; Hamid et al., 2017b; ILRI, 2004

\section{Buffalo}

The water buffaloes of Bangladesh may be grouped into types on the basis of their history of domestication, distribution and morphology. These are (i) Native buffaloes in the eastern part. (ii) Native buffaloes in the western part, (iii) Native buffaloes in the central part, (iv) Native buffaloes in the southern part and (v) Nili-Ravi breed in the Buffalo Breeding Farm at Khulna (Faruque, 2000).

As described above there are about four types of native buffaloes in the country and all of them are used widely in different regions. At the beginning, the exotic buffalo germplasms Nili-Ravi was imported to use widely for crossing with the local cows and the Nili-Ravi is at risk at present (Table 1). The buffalo populations of Bangladesh during last 10 years are presented in Table 2.

Blood protein polymorphism studied by Amano et al. (1987) indicates the existence of 7 polymorphic loci in buffalo populations of Bangladesh. These are albumin, transferrin, haemoglobin- $\alpha$, haemoglobin- $\beta$, carbonic anhydrase, alkaline phosphatase and peptidase-B. $A l b^{X}$, gene of typical swamp buffalo was found only in the populations of the eastern and southern part. $T f^{A}$, gene of typical swamp buffalo was detected only in the population of the eastern part. Amano et al. (1987) determined the karyotypes of water buffaloes of Bangladesh. They reported 50 chromosomes for the water buffaloes of the central part and 48 chromosomes for those of the eastern part (Sylhet district). The mtDNA cytochrome $b$ gene sequence of different populations of water buffaloes of Bangladesh also reveals the existence of swamp 
buffaloes in the Sylhet district. The genotypes determined indicate that water buffaloes of the western and the central part are river type. The water buffaloes of the north-eastern part are swamp type and those of the south eastern part are river type. The water buffaloes of the southern part are swamp type or crossbred type (Swamp X Nili-Ravi). The list of indigenous, exotic and crossbred buffalo genetic diversity and their distribution in Bangladesh are presented in Table 4.

Table 4. List of Indigenous, Exotic and Crossbred Buffalo Genetic diversity and their distribution in Bangladesh

\begin{tabular}{|c|c|c|c|}
\hline $\begin{array}{l}\text { Genetic } \\
\text { diversity }\end{array}$ & Breed/Type & $\begin{array}{l}\text { Geographic } \\
\text { distribution }\end{array}$ & Agro-ecological Zone \\
\hline \multirow[t]{4}{*}{ Indigenous } & River type & Plain land & $\begin{array}{l}\text { Brahmaputra-Jamuna } \\
\text { flood plain area }\end{array}$ \\
\hline & Swamp type & $\begin{array}{l}\text { Marshy land in the } \\
\text { north eastern }\end{array}$ & $\begin{array}{l}\text { Megna-Ganges tidal } \\
\text { flood plain area }\end{array}$ \\
\hline & Wild Arni type & $\begin{array}{l}\text { Coastal area in the } \\
\text { south }\end{array}$ & Coastal belt \\
\hline & Nili-Ravi & Government Farm & \multirow{2}{*}{$\begin{array}{l}\text { Both of the above } \\
\text { geographical areas }\end{array}$} \\
\hline Exotic & $\begin{array}{l}\text { Migrated Indian } \\
\text { buffalo }\end{array}$ & Central part & \\
\hline \multirow{3}{*}{ Crossbred } & Nili-Ravi cross & $\begin{array}{l}\text { Coastal area in the } \\
\text { south } \\
\text { Surrounding Indian } \\
\text { border }\end{array}$ & \multirow{3}{*}{$\begin{array}{l}\text { Both of the above } \\
\text { geographical areas }\end{array}$} \\
\hline & Murrah cross & $\begin{array}{l}\text { Surrounding Indian } \\
\text { border }\end{array}$ & \\
\hline & $\begin{array}{l}\text { River type } \times \\
\text { Swamp type }\end{array}$ & - & \\
\hline
\end{tabular}

Source: BLRI, 2015; Hamid et al., 2017c; ILRI, 2004

\section{Goat}

It is estimated that more than 90 percent of total goat population in Bangladesh is comprised of Black Bengal (Table 1) and the remainder being Jamunapari and their crosses (Hussain et al., 1998). The goat populations of Bangladesh during last 10 years are presented in Table 2.

Black Bengal goat has some reputed features: early sexual maturity, high prolificacy, adaptability to hot and humid environment and yields superior quality skin and meat (Amin et al., 2000, Chowdhury et al., 2002). The coat color of Black Bengal goat is not only black but black \& white, brown, brown and white $\&$ white are also common in the population. 
Black Bengal goat is more or less evenly distributed throughout the country. But concentration is relatively higher in the north-western areas of Bangladesh and it belongs to the high gangas river flood plain agro-ecological zone. Moreover, they are also found throughout the eastern and north eastern India from Bihar through northern Orissa to entire West Bengal, Assam, Monipur, Tripura and Meghalay province.

Jamunapari, an Indian bigger size goat breed is popularly known as Ram Chhagal. They are found in a limited scale in urban and peri-urban areas of Bangladesh in the form of pure or Jamunapari x Black Bengal cross with varying degrees of inheritance. They are reared both in intensive and semi intensive management system. However, the population size of Jamunapari is not so large (about 6-7 \%) in the country (Table 1).

In addition, some Missionary's have few small flocks of goat in the country and they maintain exotic breeds such as Beetal and Jamunapari in a limited scale aiming at producing bucks for distribution among the landless and marginal farmers as a part of their poverty alleviation programme in Bangladesh. Their target is to produce crossbred kids with improved production potentials (particularly, milk) to meet the demands of landless and marginal farmers. However, the Govt. restricted crossbreeding programme of Black Bengal goats at present. The list of indigenous, exotic and crossbred goat genetic diversity and their distribution in Bangladesh are presented in Table 5.

Nozawa and Katsumata, 1984 reported blood protein polymorphism at 7 loci (Hball.Tf, Alp, pa-3, Amy, MDH-A).

Table 5. List of Indigenous, Exotic and Crossbred Goat Genetic diversity and their distribution in Bangladesh

\begin{tabular}{|c|c|c|c|}
\hline $\begin{array}{l}\text { Genetic } \\
\text { diversity }\end{array}$ & Breed/Type & Geographic distribution & Agro-ecological Zone \\
\hline \multirow[t]{2}{*}{ Indigenous } & Black Bengal & Throughout the country & All agro- ecological zones \\
\hline & Jamunapari & $\begin{array}{l}\text { Concentrated in } \\
\text { northern and } \\
\text { northeastern districts }\end{array}$ & $\begin{array}{l}\text { Tista meander flood plain, } \\
\text { Karatoya-Bangali flood } \\
\text { plain and lower Atrai basin }\end{array}$ \\
\hline \multirow{4}{*}{ Exotic } & Beetal & Western part & \\
\hline & Sirohi & Western part & - \\
\hline & Beetal cross & In the western part & - \\
\hline & Sirohi cross & In the western part & - \\
\hline Crossbred & $\begin{array}{l}\text { Black Bengal } \\
\times \text { Jamnapari }\end{array}$ & $\begin{array}{l}\text { Concentrated in } \\
\text { northern and } \\
\text { northeastern districts }\end{array}$ & $\begin{array}{l}\text { Tista meander flood plain, } \\
\text { Karatoya-Bangali flood } \\
\text { plain and lower Atrai basin }\end{array}$ \\
\hline
\end{tabular}

Source: BLRI, 2015; ILRI, 2004 


\section{Sheep}

Sheep in Bangladesh are mostly indigenous non-descript type and it is sparsely distributed throughout the country (Table 1). BLRI collected different native sheep germplasms from different regions of the country and it has taken step for evaluation of production and reproduction performances. In collaboration with International Livestock Research Institute (ILRI), Kenya the Dept. of Animal Breeding and Genetics of Bangladesh Agricultural University, Mymensingh has started the process for genetic characterization of native sheep of Bangladesh. The sheep populations of Bangladesh during last 10 years are presented in Table 2.

The rams of exotic breeds were imported in 1965, 1976 and 1984 from Pakistan (Lohi), New Zealand and Australia (Romney Marsh, Suffolk and Parendale) to develop native sheep. However, the impact of imported sheep samples on the national sheep population is negligible. Garole sheep are found in Sundarban area in the southern part of Bangladesh. It is reported to exist in the coastal region of the country. They are reputed for multiple births and reported to have contributed to the Boorola Merino stain of Australia (Sharma et al., 1999). The list of indigenous, exotic and crossbred sheep genetic diversity and their distribution in Bangladesh are presented in Table 6. Blood protein polymorphism of 11 loci was reported but large frequency differences were observed at Alb, Tf, x-p, Dia, Ly and K (Tsunoda et al., 1998).

Table 6. List of Indigenous, Exotic and Crossbred Sheep Genetic diversity and their distribution in Bangladesh

\begin{tabular}{|c|c|c|c|}
\hline Genetic diversity & Breed/Type & Geographic distribution & Agro-ecological Zone \\
\hline \multirow[t]{6}{*}{ Indigenous } & $\begin{array}{l}\text { Non-descript } \\
\text { Deshi }\end{array}$ & $\begin{array}{l}\text { Throughout the country with } \\
\text { a relatively higher } \\
\text { concentration in }\end{array}$ & $\begin{array}{l}\text { Lower Atrai basin, Active } \\
\text { Brahmaputra and Jamuna } \\
\text { flood plain }\end{array}$ \\
\hline & & $\begin{array}{l}\text { Noakhali and Charlands } \\
\text { districts }\end{array}$ & $\begin{array}{l}\text { Middle Meghna flood plain } \\
\text { Meghna flood plain and }\end{array}$ \\
\hline & & $\begin{array}{l}\text { Medium concentration in } \\
\text { Rajshahi and Tangail } \\
\text { districts }\end{array}$ & $\begin{array}{l}\text { Lower Meghna flood plain } \\
\text { Chittagong } \\
\text { coastal plain }\end{array}$ \\
\hline & & $\begin{array}{l}\text { Lower concentration in } \\
\text { greater Rangpur, Sylhet, } \\
\text { Dhaka and }\end{array}$ & \\
\hline & & Comilla districts & \\
\hline & Garole & $\begin{array}{l}\text { Sundarban area in the } \\
\text { southern part of Bangladesh }\end{array}$ & Ganges Tidal floodplain \\
\hline Exotic & Muzaffarbadi & Western part & - \\
\hline Crossbred & $\begin{array}{l}\text { Muzaffarbadi } \\
\text { cross }\end{array}$ & In the western part & - \\
\hline
\end{tabular}

Source: BLRI, 2015; ILRI, 2004 


\section{Chicken}

The chicken germplasms of Bangladesh is composed of indigenous or native type, exotic type, crossbred type and commercial hybrid. The native germplasms; such as Non-descript Deshi, Naked Neck and Hilly are the main germplasms of indigenous chicken (Bhuiyan et al., 2005). On the other hand; Aseel and Native dwarf are the rare germplasms of indigenous chicken. The non-descript Deshi chicken is more acceptable to rural people as an important source of meat and eggs (Barua and Howlider, 1990) due to lower nutritional demand and higher resistance to diseases and heat stress. But these potential genetic resources are undergoing genetic erosion due to continuous introduction of exotic stock from developed country and their indiscriminate crossing with the indigenous chickens. The exotic chicken such as, White Leghorn (WL), White Rock (WR), White Cornish (WC), Rhode Island Red (RIR), Australorp, Fayoumi, Barred Plymouth Rock (BPR) etc. are reared in different management systems in the country. The crossbred of different chickens such as, Deshi x WL, Deshi x WC, Deshi x RIR, Deshi x Fayoumi, WL x Fayoumi, RIR x Fayoumi, Aseel x Australorp, RIR x Naked Neck, WL x Naked Neck are also used in the country. There are many commercial hybrids of chickens such as grandparent stock (GP), parent stock (PS), commercial broiler, commercial layer which are used widely for meat and egg production in the country (Table 1). The chicken populations of Bangladesh during last 10 years are presented in Table 2.

The volume of work pertaining to the genetic constitution of the indigenous chickens of Bangladesh is very thin. In the 1980s collaboration between Japan and Bangladesh Agricultural University attempted to clarify the gene constitution at the morphological and blood group loci of the Deshi chicken in Bangladesh (Okada et al., 1988, Zaman et al., 1991). Genetic distance was estimated from gene frequencies at 4 blood groups and plasma polymorphic proteins (the AKP, AKP-2, ES-1, Amy-1, Amy-3, Alb, Pas and Tf loci). Okada et al. (1988) suggested that the average genetic distances between the Domestic fowl and Jungle fowl were small for the Red Jungle fowl, intermediate for the Grey Jungle fowl, and very large for the Ceylonese and the Green Jungle fowls.

The gene frequencies at morphological loci were also used to compare chickens of different districts (geographical areas of the country). The morphological characteristics observed were: a) comb shape; b) ear lobe colour; c) feather colour; and d) shank colour. Concerning the gene frequency at each locus some variations were observed among the districts. Good variation in the frequencies of the E and I alleles controlling feather colour was noticed. The genetic distances among indigenous Deshi populations were very small but the distance between the Deshi and Aseel was relatively large which almost corresponded to the differences between the breeds. These studies further revealed that no systematic selection had been carried out on those morphological characteristics of the indigenous chickens of Bangladesh. The list of indigenous, exotic and crossbred chicken genetic diversity and their distribution in Bangladesh are presented in Table 7. 
Table 7. List of Indigenous, Exotic and Crossbred Chicken Genetic diversity and their distribution in Bangladesh

\begin{tabular}{|c|c|c|c|}
\hline Genetic diversity & Breed/Type & Geographic distribution & Agro-ecological Zone \\
\hline \multirow[t]{7}{*}{ Indigenous } & Non-descript Deshi & Throughout the country & All agro-ecological zones \\
\hline & Naked Neck & Throughout the country & All agro-ecological zones \\
\hline & Aseel & Brahmanbaria district & $\begin{array}{l}\text { Middle Meghna flood } \\
\text { plain }\end{array}$ \\
\hline & Hilly & Throughout the Country & Chittagong coastal plain \\
\hline & Jungle Fowl & $\begin{array}{l}\text { Chittagong, Chittagong } \\
\text { Hill Tracts, Sundarbans, } \\
\text { Rajendrapur }\end{array}$ & $\begin{array}{l}\text { Chittagong coastal plain, } \\
\text { Old Brahmaputra flood } \\
\text { plain area }\end{array}$ \\
\hline & Fayoumi & All over the country & \\
\hline & RIR & Government Farms & All agro-ecological zones \\
\hline \multirow[t]{5}{*}{ Exotic } & $\begin{array}{l}\text { White Leghorn } \\
\text { (WL) }\end{array}$ & Government Farms & \\
\hline & Broiler strain & Throughout the Country & All agro-ecological zones \\
\hline & Layer strain & Throughout the Country & All agro-ecological zones \\
\hline & Fayoumi X RIR & In the western part & \\
\hline & $\begin{array}{l}\text { Commercial layer } \\
\text { hybrids }\end{array}$ & All over the country & All agro-ecological zones \\
\hline Crossbred & $\begin{array}{l}\text { Commercial broiler } \\
\text { hybrids }\end{array}$ & All over the country & \\
\hline
\end{tabular}

Source: BLRI, 2015; ILRI, 2004

\section{Duck}

Similar to chicken, Bangladesh has got different types of duck germplasm and they are reared through different systems in different regions of the country. Duck genetic resources of the country are composed of indigenous or native, improved native, exotic and their crosses. Most of the duck populations in the country are native duck like Indigenous Non-descript, Deshi White, Deshi Black, Nageshwari, Sylhet Mete, Cinahanh etc. The former three native ducks are used widely at farm levels (Table 1). The duck populations of Bangladesh during last 10 years are presented in Table 2.

Bangladesh Livestock Research Institute (BLRI) has developed two types of native duck through long time selective breeding (Islam et al., 2014). The ducks are named as BLRI-1 and BLRI-2. Khaki Campbell, Indian Runner and Jending are the three exotic ducks used widely at farm level and the White Pekin, Cherry Valley, Thailand Black and Muscovy is limited to some duck farms in the public sector (Table 1). Although the crossbred of different ducks are used in the country in different farming systems, but unfortunately no information was recorded/available in this cross 
breeding program. Presently, some cross breeding program is running by Department of Livestock Services (DLS) and Bangladesh Agricultural University (BAU). The DLS started cross breeding of different ducks, such as Jending $\mathrm{x}$ Thailand Black, Indian Runner x Thailand Black, White Pekin x Thailand Black since the end of 2017 in their own farm. The Department of Poultry Science of BAU has running a cross breeding program of White Pekin $\mathrm{x}$ Thailand Black since middle of 2018. The list of indigenous, exotic and crossbred duck genetic diversity and their distribution in Bangladesh are presented in Table 8.

Table 8. List of Indigenous, Exotic and Crossbred Duck Genetic diversity and their distribution in Bangladesh

\begin{tabular}{|c|c|c|c|}
\hline $\begin{array}{l}\text { Genetic } \\
\text { diversity }\end{array}$ & Breed/Type & Geographic distribution & Agro-ecological Zone \\
\hline \multirow[t]{8}{*}{ Indigenous } & Non-descript Deshi & $\begin{array}{l}\text { Kishoregonj, Netrokona, } \\
\text { Sylhet, All over Bangladesh }\end{array}$ & All agro-ecological zones \\
\hline & Desi White & All over Bangladesh & All agro-ecological zones \\
\hline & Desi Black & All over Bangladesh & All agro-ecological zones \\
\hline & Nageshwari & $\begin{array}{l}\text { In Sylhet district in the south } \\
\text { east }\end{array}$ & All agro-ecological zones \\
\hline & Sylhet Mete & $\begin{array}{l}\text { In Sylhet district in the south } \\
\text { east }\end{array}$ & All agro-ecological zones \\
\hline & Indian Runner & All over the country & \\
\hline & Khaki Campbell & All over Bangladesh & All agro-ecological zones \\
\hline & Jending & $\begin{array}{l}\text { Duck farms and selective } \\
\text { places of the country }\end{array}$ & \\
\hline \multirow{3}{*}{ Exotic } & White Pekin & $\begin{array}{l}\text { Limited to duck farms in the } \\
\text { public sector }\end{array}$ & - \\
\hline & Muscovy & $\begin{array}{l}\text { Limited to duck farms in the } \\
\text { public sector }\end{array}$ & All agro-ecological zones \\
\hline & $\begin{array}{l}\text { Indigenous X Khaki } \\
\text { Campbell, Indigenous } \\
\text { X Indian Runner, } \\
\text { Indigenous X Jending }\end{array}$ & All over Bangladesh & All agro-ecological zones \\
\hline \multirow[t]{2}{*}{ Crossbred } & $\begin{array}{l}\text { Jending X Thailand } \\
\text { Black, Indian Runner } \\
\text { X Thailand Black, } \\
\text { White Pekin X } \\
\text { Thailand Black }\end{array}$ & $\begin{array}{l}\text { Limited to government duck } \\
\text { farms }\end{array}$ & $\begin{array}{l}\text { Ongoing cross breeding } \\
\text { program }\end{array}$ \\
\hline & $\begin{array}{l}\text { White Pekin X } \\
\text { Thailand Black }\end{array}$ & $\begin{array}{l}\text { Bangladesh Agricultural } \\
\text { University's poultry farm }\end{array}$ & $\begin{array}{l}\text { Ongoing cross breeding } \\
\text { program }\end{array}$ \\
\hline
\end{tabular}

Source: BLRI, 2015; ILRI, 2004 


\section{Pigeon}

There is a single native type of pigeon but about six (6) exotic types of pigeon are found in the country (Table 1). Indigenous "Jalali" pigeon is widely used by peoples. Most of them are reared on free flying system i,e the farmers provide only shelter for their squab production. They used to collect their feed from different sources. The list of indigenous and exotic pigeon genetic diversity and their distribution in Bangladesh are presented in Table 9.

Table 9. List of Indigenous and Exotic Pigeon Genetic diversity and their distribution in Bangladesh

\begin{tabular}{c|l|l|c}
\hline $\begin{array}{c}\text { Genetic } \\
\text { diversity }\end{array}$ & \multicolumn{1}{c}{ Breed/Type } & Geographic distribution & Agro-ecological Zone \\
\hline Indigenous & Non-descript Deshi & Throughout the country & All agro-ecological zones \\
& Jalali & All over the country & All agro-ecological zones \\
& Siraji & All over the country & All agro-ecological zones \\
& Giribuj & All over the country & All agro-ecological zones \\
& Loton & All over the country & All agro-ecological zones \\
& King & All over the country & \\
& Horner & All over Bangladesh & \\
Exotic & Fantail & All over Bangladesh & All agro-ecological zones \\
& Pouters & All over Bangladesh & \\
& Tumblers & All over Bangladesh & \\
\hline
\end{tabular}

Source: BLRI, 2015; ILRI, 2004

\section{Quail}

Both native and exotic types of quail are available in the country. Jungle quails are mostly found in the forest area under free flying conditions but indigenous type is reared in semi-urban area under intensive condition. Japanese, Brown and Dhakai are the three exotic types of Quail are reared in the semi-intensive or intensive systems. The exotic Japanese Quail is widely used and indigenous type is at the risk of extinction (Table 1). The list of indigenous and exotic quail genetic diversity and their distribution in Bangladesh are presented in Table 10. 
Table 10. List of Indigenous and Exotic Quail Genetic diversity and their distribution in Bangladesh

\begin{tabular}{l|l|c|c}
\hline Genetic diversity & \multicolumn{1}{c|}{ Breed/Type } & $\begin{array}{c}\text { Geographic } \\
\text { distribution }\end{array}$ & Agro-ecological Zone \\
\hline Indigenous & $\begin{array}{l}\text { Non-descript } \\
\text { Deshi } \\
\text { Jungle }\end{array}$ & Semi-urban & All agro-ecological zones \\
& Japanese & Hilly forest & All agro-ecological zones \\
Exotic & Brown & Semi-urban & All agro-ecological zones \\
& Dhakai & & \\
\hline
\end{tabular}

Source: BLRI, 2015; ILRI, 2004

\section{Guinea fowl}

Native Guinea fowl of indigenous type is reared by the farmers and found to be popular in some regions of the country. However, no survey works on their habitats or production system or any initiative for characterization of the germplasm is done except some individual evaluation at farm level (Table 1).

\section{CONCLUSION}

The farm animal genetic diversity is very important for a country's economic, social and cultural aspects. It is very essential for a country to demonstrate the linkages between biodiversity, livelihoods and socio-economic structure. The essential way of achieving sustainable conservation of biodiversity is through collaboration between local communities, national body or institution of a country.

\section{REFERENCES}

Amano, T., Namikawa, T., Okada, I., Hasnath, M.A., Faruque, M.O. and Majid, M.A. (1987). Karyotypes and blood protein polymorphisms of native buffaloes in Bangladesh. In: Genetic studies on breed differentiation of native domestic animals in Bangladesh. Part II. p. 117-128.

Amin, M.R., Hussain, S.S. and Islam, A.B.M. (2000). Reproductive peculiarities and litter weight in different groups of Black Bengal does. Asian-Australasian Journal of Animal Sciences, 14: 1-5.

Barua, A. and Howlider, M.A.R. (1990). Prospect of native chickens in Bangladesh. Poultry Adviser, 23: 57-61.

Bangladesh Livestock Research Institute. (2015). Farm Animal Genetic Resource in Bangladesh. Annual Report on Livestock, Division of Livestock Statistics, Ministry of Fisheries and Livestock, Farmgate, Dhaka, Bangladesh.

Bangladesh Livestock Research Institute. (2004). First Report on Animal Genetic Resources of Bangladesh, Government of Bangladesh, Dhaka, Bangladesh. p. 42. 
Bhuiyan, A.K.F.H., Bhuiyan, M.S.A. and Deb, G.K. (2005). Indigenous Chicken genetic resources in Bangladesh: Current status and future outlook. Animal Genetic Resources Information's Bulletin., 36: 73-84.

Chowdhury, S.A., Faruque, S. and Asaduzzaman, M. (2002). Improvement of Black Bengal goat through selective breeding, Research report, Bangladesh Livestock Research Institute, Savar, Dhaka, Bangladesh.

Department of Livestock Services. (2019). Annual report on livestock. Division of Livestock Statistics, Ministry of Fisheries and Livestock, Farmgate, Dhaka, Bangladesh.

Department of Livestock Services. (2016). Annual report on livestock. Division of Livestock Statistics, Ministry of Fisheries and Livestock, Farmgate, Dhaka, Bangladesh.

Department of Livestock Services. (2014). Annual report on livestock. Division of Livestock Statistics, Ministry of Fisheries and Livestock, Farmgate, Dhaka, Bangladesh.

Department of Livestock Services. (2010). Annual report on livestock. Division of Livestock Statistics, Ministry of Fisheries and Livestock, Farmgate, Dhaka, Bangladesh.

Faruque, M.O. (2000). Research report on "Identification of best genotype of buffaloes for dairy purpose in Bangladesh and to improve their productivity". Bangladesh Agricultural Research Council, Dhaka, Bangladesh.

Hamid, M.A., Rahman, M.A., Ahmed, S. and Hossain, K.M. (2017a). Status of Poultry Industry in Bangladesh and the Role of Private Sector for its Development. Asian Journal of Poultry Science, 11(1): 1-13.

Hamid, M.A., Rahman, A., Zaman, M.A. and Hossain, K.M. (2017b). Cattle Genetic Resources and their Conservation in Bangladesh. Asian Journal of Animal Science, 11(2): 54-64.

Hamid, M.A., Zaman, M.A., Rahman, A. and Hossain, K.M. (2017c). Buffalo Genetic Resources and their Conservation in Bangladesh. Research Journal of Veterinary Science, 10(1): 1-13.

Hussain, S.S., Amin, M.R. and Islam, A.B.M.M. (1998). Goat production and its breeding strategy in Bangladesh. First national workshop on Animal Breeding. p. 17-36. November 26, 1998, Bangladesh Agricultural University, Mymensingh.

International Livestock Research Institute. (2004). Status, trends, utilization and performance of FAnGR of Bangladesh. Consultancy report of GEF-UNEP-ILRI FAnGR Asia Project, ILRI, Kenya. p. 49.

Islam, M.S., H. Khatun, M.N. Islam, S. Faruque and M.S.K. Sarker. (2014). Study on the Productive and Reproductive Performances of BLRI-1 and BLRI-2 Ducks in Bangladesh. The Agriculturists, 12(1): 10-14.

Tsunoda, K., Doge, K., Hasnath, M.A., Rajbhandary, H.B., Xu, W., Zhanchiv, T. and Chau, B.L. (1998). Genetic polymorphism of plasma vitamin D-binding protein (Gc) in some Asian sheep. Asian-Australasian Journal of Animal Sciences, 11(3): 318-322.

Namikawa, T., Amano, T., Okada, I., Hasnath, M.A., Haque, A.K.F. and Majid, M.A. (1987). Karyotypes, blood groups and blood protein polymorphisms in the goyal, goyal-cattle hybrids and native cattle of Bangladesh. In: Genetic studies on breed differentiation of native domestic animals in Bangladesh. Part II. p. 105-115. 
Nozawa, K. and Katsumata, M. (1984). Coat color polymorphism in the Black Bengal Goats. Genetic Studies on Breed Differentiation of the Native Domestic Animals in Bangladesh. Investigation on the Cattle, Water Buffaloes, Horses, Sheep, Goats and Wild Musk Shrews. p. 87-99.

Okada, I. Maeda, Y., Hashiguchi, T., Hasnath, M.A., Faruque, M.O. and Majid, M.A. (1988). Gene constitution of indigenous chicken in Bangladesh. Japanese Poultry Science, 25: $15-26$.

Sharma, R.C., Arora, A.I., Narula, H.K. and Singh, R.N. (1999). Characteristics of Garole sheep in India. Animal Genetic Resource Information, 26: 57-64.

Zaman, S., Ali, A., Faruque, M.O. and Bhuiyan, A.K.F.H. (1991). Transferrin polymorphism and growth rate in Rhode Island Red, Crossbred and native chicken. Asian-Australasin Journal of Animal Science, 4: 231-234. 